\title{
Erratum to: Angiotensin-converting enzyme inhibitors of Bothrops jararaca snake venom affect the structure of mice seminiferous epithelium
}

\author{
Carlos Alberto-Silva ${ }^{1 *}$, Joyce M. Gilio², Fernanda C. V. Portaro ${ }^{3}$, Samyr M. Querobino ${ }^{1}$ and Antonio C. M. Camargo ${ }^{2}$
}

Unfortunately, the original version of this article [1] contained an error. The conclusion was included incorrectly. The conclusion has been corrected in the original article and is also included correctly below.

\section{Conclusion}

Overall, the results obtained from the proline-rich snake-venom oligopeptide suggest that the alterations in the structure of the seminiferous epithelium in mice following BPP-10c and BPP-AP treatment, but not treatment with BPP-11e, are dependent on their primary molecular structure. This study offers new perspectives for the elucidation of possible mechanisms involved in the impairment of spermatogenesis by BPP-10c and BPP-AP, thereby providing new insight into the biological features of the snake venom.

\section{Author details}

${ }^{1}$ Center for Natural and Humanities Sciences (CCNH), Federal University of ABC (UFABC), R. Santa Adélia, 166, Santo André, SP CEP 09210-170, Brazil. ${ }^{2}$ Center for Applied Toxinology, Butantan Institute, São Paulo, SP, Brazil.

${ }^{3}$ Laboratory of Immunochemistry, Butantan Institute, São Paulo, SP, Brazil.

Received: 4 August 2015 Accepted: 5 August 2015

Published online: 26 August 2015

\section{Reference}

1. Alberto-Silva C, Gilio P, Querobino C. Angiotensin-converting enzyme inhibitors of Bothrops jararaca snake venom affect the structure of mice seminiferous epithelium. J Venomous Anim Toxins Incl Tropical Dis. 2015;21:27.

\footnotetext{
* Correspondence: carlos.asilva@ufabc.edu.br

${ }^{1}$ Center for Natural and Humanities Sciences (CCNH), Federal University of ABC (UFABC), R. Santa Adélia, 166, Santo André, SP CEP 09210-170, Brazil Full list of author information is available at the end of the article
}

Submit your next manuscript to BioMed Central and take full advantage of:

- Convenient online submission

- Thorough peer review

- No space constraints or color figure charges

- Immediate publication on acceptance

- Inclusion in PubMed, CAS, Scopus and Google Scholar

- Research which is freely available for redistribution

Submit your manuscript at www.biomedcentral.com/submit
() Biomed Central 